Ger J Exerc Sport Res 2020 · 50:444-452 https://doi.org/10.1007/s12662-020-00672-9 Received: 15 October 2019

Accepted: 28 July 2020

Published online: 2 September 2020

(c) The Author(s) 2020

\section{Introduction}

The effect of extensive social media usage for the self-concept is a highly studied subject within social science, especially psychology, offering a diverse discussion about its possible links to mental health issues (Lup, Trub, \& Rosenthal, 2015; Royal Society for Public and Health, 2017). Thus, current research often seems to challenge Festinger's (1954) early assumption that objective criteria are more important than social comparative values in the individual self-assessment. Although, especially in modern, informal sporting activities, such as parkour, an athlete gains a variety of information and feedback from both ends: from their training in real life; as well as from social comparison within the primarily internet-based community (Holzmüller, 2018). Sharing jumps in virtual realities seems to be nearly as important as doing them in the real world and online communication is a highly necessary tool for traceurs (parkour athletes) to even partake in training and events at all (Braumüller, 2020; Wheaton \& Gilchrist, 2012). Despite this strong relationship between informal sports like parkour and social media, the current state of research lacks evidence on the determinants and especially the social media-related determinants of the physical self-concept of athletes. Physical self-concept can be understood as the self-perception about one's physical self(Marsh, Martin, \& Jackson, 2010). Therefore, the aim of the present study is to ascertain the most relevant determinants for the self-assess-

\author{
Philipp Julian Johannes Holzmüller ${ }^{1}$ Birgit Braumüller ${ }^{2}$ (I) \\ 'German Sport University Cologne, Cologne, Germany \\ ${ }^{2}$ Institute of Sociology and Gender Studies, German Sport University Cologne, Cologne, Germany
}

\title{
Climb ups or thumbs ups?
}

\section{Identifying determinants for parkour-related physical self-concepts of traceurs based on training data and social media use}

ment of one's parkour skills, conducting a secondary data analysis based on quantitative data and the theoretical model of the parkour-related physical self-concept (pkPSC) by Holzmüller (2018). The purpose is to show whether and to what extent, real-life experience, social media use and sociodemographic characteristics determine an athlete's parkour-related physical self-concept. Hence, this study will help to understand the communities behind informal modern sports and the ways online and offline practices influence the self-concepts of their members.

\section{Literature review}

Processes of mediatization have deeply changed social, cultural, and communicative structures in various societal fields, among which sport appears to play a distinct role due to its physical character (Krotz, 2017). Growing social media use, particularly amongst adolescents, is often speculated to happen at the expense of sporting activities. But empirical research in this field lacks clarity and findings support displacing, engaging or independent relationships between sport activities and social media use (Braumüller \& Hartmann-Tews, 2017; Spengler et al., 2015). Two findings are almost constantly evident in research literature on the relationship of sport and social media use: First, if social media is used in sport-related contexts, the effects on sport activities are rather enhancing (Braumüller \& HartmannTews, 2017). Second, informal athletes particularly benefit from engaging relationships between doing sport and using social media (Bock, 2017; Braumüller, 2016; Jones, 2015; Schwier \& Erhorn, 2015) as they are enabled to virtually connect and communicate with their networks and integrate the "medial and physical practice” (Schwier, 2008, p. 273).

Turning to the question of tangible implications of using social networks for sport activities, qualitative research identified the following perceptions of young adults: A facilitated organization of and access to sports; a professionalization of practice and improvement of sporting abilities and an increased motivation and incitement for playing sports (Braumüller, 2020). The organizational implication is particularly important for informal athletes (Braumüller, 2020). Focusing likewise on informal settings Setzer, Ernst, and Miethling (2014) identified the need to belong to the community and to gain recognition for one's performance as major drivers for using Facebook among windsurfers. Summing up research on using social media in general sports-related (not particularly informal) contexts four dimensions of gratifications occur: social gratifications (e.g., interaction, showing unity and fellowship, support), information (e.g., information-seeking, advice, knowledge), entertainment (passing time), and selfstaging (David et al., 2018; Braumüller \& Hartmann-Tews, 2017; Kim, Kim, \& Choi, 2016; O’Reilly, Berger, Hernandez, Parent, \& Seguin, 2012).

Having shown that sports (especially informal sports) and social media use (es- 


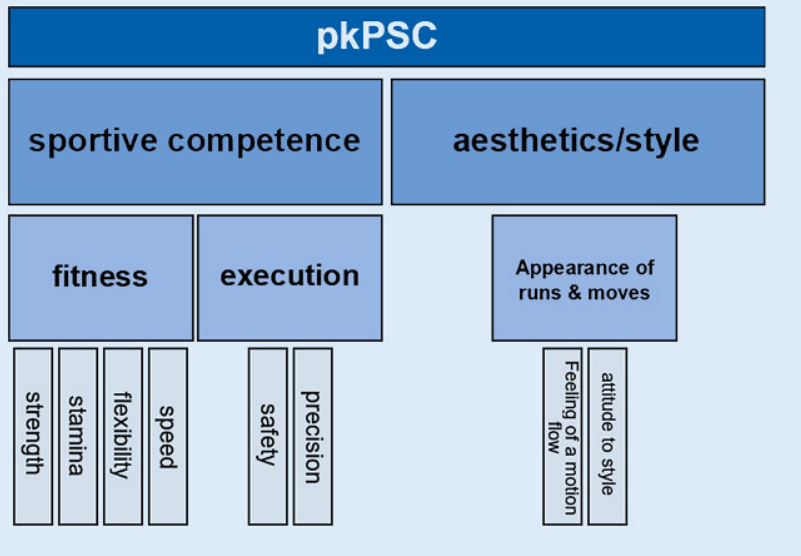

Fig. $1 \varangle$ Parkourrelated physical self-concept model (Holzmüller, 2018)

pecially sport-related social media use) are enhancing activities, the next step is to contextualize these findings with their effects on different self- or body-concepts in general. Jones (2015) looked into the effects of active social media use on the general self-concepts of YouTube producers, based on Cooleys' (1902) looking glass lens theory. There, she identified confidencegains, a more positive acceptance of one's physical appearance or self-empowerment, which she linked to overcoming negative comments or the producer's new role in an interactive community (Jones, 2015). Besides potentially positive effects of social media use, too much screen time is also repeatedly linked to fatigue (Suchert, Hanewinkel, \& Isensee, 2016) and possible psychological issues (Chou \& Edge, 2012; Fox \& Moreland, 2015; Gonzales \& Hancock, 2011). A metaanalysis from Grabe, Ward, and Hyde (2008), tackling the issue of body-image in women, was able to show a decreased self-worth after a comparison with idealized online references and even an internalization of medially spread ideals. Body image, in this case, was defined as "thoughts, feelings, and behavioral responses related to one's body" (Grabe et al., 2008, p. 462). Döring (2014) likewise confirms negative effects of comparing one's abilities to virtual others, whereas Braumüller (2020) found positive implications in terms of increasing motivation after comparing one's performance with virtual others. But, Want (2009) as well as Döring (2014) stated that first and foremost, already existing uncertainties and behavioral patterns would merely be reinforced, as the rationale of structure reinforcing implies.

Focusing on the controversially discussed link between physical activity and the general physical self-concept (according to Shavelson, Hubner, \& Stanton, 1976), a systematic literature review was able to collect strong evidence in favor of a significant positive association between the two (Babic et al., 2014). Age and sex were examined to be key moderators of this association between physical activity and physical self-concept in children and adolescents (Babic et al., 2014). Also, positive effects of general physical activity (Balsalobre, Sánchez, \& Suárez, 2014; Olmedilla, Toro, \& Abenza, 2016) as well as training frequency (Esnaola \& Zulaika, 2009) have been revealed to impact the physical and general self-concept (as defined by Shavelson et al., 1976; and García \& Musitu, 2001). Athletes who trained frequently had a significantly more positive assessment of their own physical condition and physical selves than their less active counterparts (Balsalobre et al., 2014; Esnaola \&Zulaika, 2009; Olmedilla et al., 2016). Likewise, sporting skill and self-concept seem to have a reciprocal effect on each other, as examined by Marsh, Chanal, \& Sarrazin (2006) in gymnastics. They stated that, on the one hand, a positive gymnastic self-concept is said to help achieve positive outcomes regarding the according physical skills, exercise adherence and more, while, on the other hand, good sporting performances increased the self-concept as well (Marsh et al., 2006). Therefore, the concept of self seems to play a prominent role in sporting success and satisfaction, as well as the other way around.

Since the current study focuses on the physical self-concepts of traceurs, i.e., the self-perception of one's physical self as a traceur, the question on the specificity of parkour-related skills, abilities and performance-aspects has to be discussed. For this purpose, the physical self-concept model of Shavelson et al. (1976) serves as the foundation, but has been adapted to the parkour-specific context, in which some new dimensions gained and others lost importance. For example, the physical appearance was supposed to be less important within the parkour community, whereas the attitude towards one's own movement-style or -fluidity (called flow) appeared to be more relevant for traceurs (Holzmüller, 2018). These adaptions for the parkour context led to the development of the parkour-related physical self-concept model (pkPSC) by Holzmüller (2018). In general, a parkour-related self-concept model seemed necessary to compare traceurs' self-concepts based on discipline specific items, whereas physical self-concept model by Shavelson et al. (1976) would have had depicted a much broader, generalized picture. This would have overlooked essential content for Holzmüller's (2018) research or included non-essential content as he stated. Still, to ensure validity and a certain comparability, the dimensions and questions of the pkPSC adapt as well as possible to other concepts like the Physical Self-Description Questionnaire by Marsh et al. (2010) or the physical self-concept by Shavelson et al. (1976). Thus, the pkPSC comprises two main categories-sportive competence and aesthetics/style - that were split up into several subcategories. Sportive competence integrated items on the fitness and the execution level, whereas aesthetics/style included the appearance of runs and movements (• Fig. 1).

In the original study Holzmüller (2018) examined if the self-assessment of the physical self-concepts of traceurs is being influenced by the group to which traceurs compare their skills. Following the rationale of the big-fish-little-pond 
effect ${ }^{1}$ with regard to the relevance of social media, the respondents were either primed to compare their skills to their local or their virtual parkour community. Contrary to the prior assumption the two quasi-randomized groups did not show significant differences in their parkour-related physical self-concept (pkPSC). Thus, in the tendency, the pkPSC of the group that was primed to compare its skills to the online community was slightly lower than the pkPSC of the group primed to the local training community, suggesting a possible influence of online activity on the pkPSC (Holzmüller, 2018).

In conclusion, social media and online activities as well as frequent training and sporting performance seem to actually influence the general and physical self-concept as well as the body image of athletes. Still, literature regarding noncompetitive or informal sports is immature and rather vague. Therefore, using original data from Holzmüller (2018) the present study aims to explain the physical self-concept of traceurs (pkPSC) by three independent types of determinants to which sociodemographic characteristics and training-related variables belong. Since parkour and social media are supposed to have a supportive and close relation, as illustrated earlier, the (parkour-related) social media use of the participants is being integrated as another independent type of determinants for the physical self-concept of traceurs. The research question is: How far is the parkour-related physical selfconcept (pkPSC) of traceurs determined by their sociodemographic characteristics, aspects of their parkour training and their social media use? To answer this question, multiple linear regression analyses were conducted to gain reliable and valid insights into the relationship of the self-assessment of parkour-related skills, parkour training, and the (parkour-related) social media use of traceurs.

\footnotetext{
1 Using this rationale, students with an objectively equal or similar academic self-concept tend to assess their own (academic) skills differently, depending on the group or class they are in (Marsh \& Parker, 1984).
}

\section{Methodological summary}

This quantitative empirical study is designed as a secondary analysis based on data from Holzmüller's previous study (2018), in which he examined the parkour-related physical self-concepts of traceurs against the background of the big-fish-little-pond effect, as previously outlined.

The data collection was conducted in 2018 via social media platforms-mainly Instagram and Facebook (Messenger $)^{2}$-on which acquainted traceurs dispersed the online link in their parkour-related online and offline networks on local, national, and international levels. This snowball technique led to a dataset containing 458 valid cases, of which 241 respondents completed the questionnaire with regard to their local training group and 217 with regard to the online community. Via a quasi-randomization respondents were assigned to these groups and underwent a specific priming to compare their parkour skills either to their local training group or to the athletes of their virtual parkour community.

Besides sociodemographic characteristics, the questionnaire asked about the participants' social media use, their parkour training as well as on their self-assessment of parkour-related physical skills. The data describe typical traceurs as male, between 20 and 29 years old, with a training experience of around 3-5 years, and a training frequency of 2-3 days per week (Holzmüller, 2018). Detailed information on the independent variables, their measurement, and their percentage distribution is depicted in $\bullet$ Table 1.

The parkour-related physical self-concept (pkPSC) is built upon the sum of the participants' rankings of 20 items on parkour-related skills on a 5-point scale from 'strongly disagree' to 'strongly agree'. For reliability analysis, Cronbach's alpha (a) was calculated to assess the internal consistency of the pkPSC, which turns out to be good and satisfying with Cronbach's $\alpha=0.876$ (Nunnally \& Bernstein, 1994). Descriptive values for the

\footnotetext{
2 Both social media networks belong to Facebook Inc. (Menlo Park, CA, USA).
}

Ger J Exerc Sport Res 2020 · 50:444-452 https://doi.org/10.1007/s12662-020-00672-9 (c) The Author(s) 2020

\section{P. J. J. Holzmüller · B. Braumüller Climb ups or thumbs ups? Identifying determinants for parkour-related physical self- concepts of traceurs based on training data and social media use}

\section{Abstract}

In postmodern times, social media is an integral part of informal sports like parkour. It potentially impacts physical activities as well as the assessment of one's physical abilities and skills. Referring to the under-researched impact on the self-assessment, this study aims to examine if the parkour-related physical self-concept can be determined by social media use, as well as parkourtraining aspects and sociodemographics. Two reference points of comparison have been considered, comparing one's skills to real or virtual parkour communities. To address this research phenomenon, multiple linear regression analyses were conducted. The results showed that a high parkourrelated physical self-concept (pkPSC) is primarily determined by the amount of time athletes put into their parkour activities. Furthermore, age and gender played an important role, indicating that being a young male appeared to be a main determinant for a higher pkPSC. Finally, posting parkour-related content in social media appeared to influence the pkPSC, although this finding might be interpreted as causality in both directions. The study identified real-life activities to be more important for the physical self-concept of traceurs; however, social media play a crucial role in the parkour community.

Keywords

Informal sports · Regression analyses · Selfassessment $\cdot$ Practice $\cdot$ Online communities

pkPSC and its central dimensions are presented in - Table 2 . The mean value for the pkPSC is 52 (standard deviation $[S D]=10.3$, range $0-80$ ) showing that the majority of respondents have a rather positive self-assessment of their parkour skills. The mean values of the central dimensions of the pkPSC differ only slightly, indicating a rather equal assessment of different skill-aspects of traceurs (• Table 2). 


\begin{tabular}{|c|c|c|c|c|c|c|c|c|}
\hline \multirow{4}{*}{$\begin{array}{l}\text { Sociodemo- } \\
\text { graphics }\end{array}$} & \multirow{4}{*}{$\begin{array}{l}\text { Gender } \\
\text { Age (in years) }\end{array}$} & Female (0) & Male (1) & \multicolumn{5}{|l|}{-} \\
\hline & & $13.2 \%$ & $86.8 \%$ & \multicolumn{5}{|l|}{-} \\
\hline & & $\begin{array}{l}\text { Under } \\
20 \text { years } \\
\text { (1) }\end{array}$ & $\begin{array}{l}20-29 \text { years } \\
(2)\end{array}$ & $\begin{array}{l}30-39 \text { years } \\
\text { (3) }\end{array}$ & $\begin{array}{l}40-49 \text { years } \\
\text { (4) }\end{array}$ & $\begin{array}{l}\text { Above } \\
49 \text { years (5) }\end{array}$ & \multicolumn{2}{|l|}{-} \\
\hline & & $19.4 \%$ & $68.1 \%$ & $10.5 \%$ & $1.3 \%$ & $0.7 \%$ & \multicolumn{2}{|l|}{-} \\
\hline \multirow{6}{*}{$\begin{array}{l}\text { Parkour } \\
\text { training }\end{array}$} & \multirow{2}{*}{$\begin{array}{l}\text { Frequency (days/ } \\
\text { week) }\end{array}$} & 1 day (1) & $2-3$ days (2) & 4-5 days (3) & 6-7 days (4) & - & & \\
\hline & & $37.9 \%$ & $46.5 \%$ & $13.4 \%$ & $2.2 \%$ & - & & \\
\hline & \multirow{2}{*}{$\begin{array}{l}\text { Training } \\
\text { experience (in } \\
\text { years) }\end{array}$} & $\leq 1$ year $(1)$ & $\begin{array}{l}>1 \text { to } 3 \text { years } \\
\text { (2) }\end{array}$ & $\begin{array}{l}>3 \text { to } 5 \text { years } \\
\text { (3) }\end{array}$ & $\begin{array}{l}>5 \text { to } 7 \text { years } \\
\text { (4) }\end{array}$ & $\begin{array}{l}>7 \text { to } 9 \text { years } \\
\text { (5) }\end{array}$ & $\begin{array}{l}>9 \text { to } 11 \text { years } \\
\text { (6) }\end{array}$ & $\begin{array}{l}>11 \text { years } \\
\text { (7) }\end{array}$ \\
\hline & & $4.6 \%$ & $14.0 \%$ & $20.7 \%$ & $21.0 \%$ & $15.1 \%$ & $14.4 \%$ & $10.3 \%$ \\
\hline & \multirow[t]{2}{*}{$\begin{array}{l}\text { Size of training } \\
\text { group }\end{array}$} & $\leq 5$ people (1) & $\begin{array}{l}6-10 \text { people } \\
(2)\end{array}$ & $\begin{array}{l}\text { 11-20 people } \\
\text { (3) }\end{array}$ & 20 or more (4) & - & & \\
\hline & & $45.8 \%$ & $32.8 \%$ & $14.5 \%$ & $6.8 \%$ & - & & \\
\hline \multirow{6}{*}{$\begin{array}{l}\text { Social media } \\
\text { use }\end{array}$} & \multirow{2}{*}{$\begin{array}{l}\text { Social media use } \\
\text { (h/day) }\end{array}$} & $\leq 1.5 \mathrm{~h}(1)$ & $>1.5$ to $4 \mathrm{~h}(2)$ & $>4$ to $6 \mathrm{~h}$ (3) & $>6 \mathrm{~h}(4)$ & - & & \\
\hline & & $51.4 \%$ & $41.5 \%$ & $4.4 \%$ & $2.6 \%$ & - & & \\
\hline & \multirow{2}{*}{$\begin{array}{l}\text { Parkour-related } \\
\text { postings }\end{array}$} & No $(0)$ & Yes (1) & - & & & & \\
\hline & & $26.6 \%$ & $73.4 \%$ & - & & & & \\
\hline & \multirow{2}{*}{$\begin{array}{l}\text { Number of } \\
\text { followed traceurs } \\
\text { on social media }\end{array}$} & $\leq 100(0)$ & $>100(1)$ & - & & & & \\
\hline & & $55.7 \%$ & $44.1 \%$ & - & & & & \\
\hline
\end{tabular}

Table 2 Descriptives of sum variable parkour-related physical self-concept (pkPSC) (range 0-80) and its core dimensions (sum variables highlighted in italic). Each single item was ranked on a 5point scale from strongly disagree' (1) to 'strongly agree' (5), in parenthese: number of single items for each dimension. Sample Size (n), Mean (M), Standard deviation (SD), Minimum value (Min), Maximum value (Max)

\begin{tabular}{|c|c|c|c|c|c|c|}
\hline & & $n$ & $\mathbf{M}$ & SD & Min & Max \\
\hline \multirow{5}{*}{$\begin{array}{l}\text { Sportive compe- } \\
\text { tence-fitness }\end{array}$} & Strength (2) & 446 & 3.92 & -0.739 & 1 & 5 \\
\hline & Flexibility (2) & 446 & 3.22 & 0.898 & 1 & 5 \\
\hline & Stamina (2) & 441 & 3.51 & 0.856 & 1.5 & 5 \\
\hline & Speed (2) & 445 & 3.64 & 0.839 & 1 & 5 \\
\hline & Sum fitness (8) & 420 & 3.58 & 0.575 & 1.75 & 5 \\
\hline \multirow{3}{*}{$\begin{array}{l}\text { Sportive compe- } \\
\text { tence-execution }\end{array}$} & Safety (2) & 442 & 3.97 & 0.695 & 1.5 & 5 \\
\hline & Precision (2) & 390 & 3.66 & 0.748 & 1.5 & 5 \\
\hline & Sum execution (4) & 386 & 3.82 & 0.614 & 1.5 & 5 \\
\hline \multirow{3}{*}{$\begin{array}{l}\text { Aesthetics-ap- } \\
\text { pearance of runs/ } \\
\text { moves }\end{array}$} & Attitude to style (2) & 409 & 3.57 & 0.717 & 1.5 & 5 \\
\hline & Feeling of motion flow (2) & 433 & 3.52 & 0.794 & 1 & 5 \\
\hline & Sum aesthetics (4) & 404 & 3.56 & 0.682 & 1.25 & 5 \\
\hline General aspects & Sum general (4) & 414 & 3.79 & 0.563 & 1.75 & 5 \\
\hline pkPSC & All Items (20) & 455 & 51.62 & 10.30 & 16 & 80 \\
\hline
\end{tabular}

To investigate the present research question, first, bivariate correlations between the independent determinants and the parkour-related physical self-concept were conducted. Afterwards, multiple linear regression models have been postulated to determine the influence of age, gender, training-related variables, and social media use on the parkourrelated physical self-concept of traceurs.
Three different multiple linear regression models were computed. The first for all participants. The second dealt with the group primed to compare its skills to the local training group and the third dealt with the group primed to compare its skills to athletes on social media. After proving the methodological requirements for each of the three models, the regression analyses were postulated using the enter method. By analyzing the correlations of the independent variables and using the statistical measures of TOL (tolerance) and VIF (variance inflation factor) a multicollinearity of the independent variables is precluded. Further preanalyses disproved heteroscedasticity and proved a normal distribution of the residuals. Therefore, the check of statistical prerequisites allowed for an application of multiple regression analyses to the data.

\section{Empirical results}

Bivariate correlation analyses between the independent determinants (sociodemographics, social media use, and parkour training) and the dependent variable pkPSC have been conducted for the overall sample (1), the social media priming group (sample 2), and the local priming group (sample 3 ) (• Table 3 ).

In the overall sample seven out of eight independent variables show a significant, but rather low correlation with the pkPSC. Both sociodemographic characteristics are significantly linked to the pkPSC, indicating that being male and younger in age is associated with a higher parkour-related physical self- 
Table 3 Bivariate Correlations between independent variables and pkPSC (dependent) for all three samples (overall, media, local). Spearman/Pearson coefficient and significance level/ $p$-value $\left({ }^{*} p \leq 0.05,{ }^{* * *} p \leq 0.001\right)$. Significant correlations are highlighted in italic

\begin{tabular}{|c|c|c|c|c|}
\hline & & $\begin{array}{l}\text { Sample } 1 \\
\text { (overall) }\end{array}$ & $\begin{array}{l}\text { Sample } 2 \\
\text { (media) }\end{array}$ & $\begin{array}{l}\text { Sample } 3 \\
\text { (local) }\end{array}$ \\
\hline \multirow{2}{*}{$\begin{array}{l}\text { Socio- } \\
\text { demo- } \\
\text { graphics }\end{array}$} & Gender & $0.327^{* * *}$ & $0.342^{* * *}$ & $0.290^{* * *}$ \\
\hline & Age & $-0.092^{*}$ & -0.118 & -0.072 \\
\hline \multirow{3}{*}{$\begin{array}{l}\text { Parkour } \\
\text { training }\end{array}$} & Frequency of parkour training & $0.273^{* * *}$ & $0.219^{* * *}$ & $0.308^{* * *}$ \\
\hline & Training experience in parkour & $0.327^{* * *}$ & $0.377^{* * *}$ & $0.276^{* * *}$ \\
\hline & Size of training group in parkour & 0.001 & -0.009 & 0.027 \\
\hline \multirow{3}{*}{$\begin{array}{l}\text { Social } \\
\text { media } \\
\text { use }\end{array}$} & Duration of social media use & $0.098^{*}$ & 0.058 & $0.140^{*}$ \\
\hline & Parkour-related postings & $0.329^{* * *}$ & $0.393^{* * *}$ & $0.241^{* * *}$ \\
\hline & $\begin{array}{l}\text { Number of traceurs followed in } \\
\text { social media }\end{array}$ & $0.299^{* * *}$ & $0.252^{* * *}$ & $0.343^{* * *}$ \\
\hline
\end{tabular}

concept. Within the parkour-related variables the frequency of training and the training experience show positive correlations with the pkPSC, whereas the size of the training groups is not significantly correlated. Regarding the third dimension, all social media related variables show significantly positive correlations with the pkPSC.

With the exception of age, the local sample confirms the findings of the overall sample, whereas in the media sample neither age nor the duration of the social media use correlate significantly with the pkPSC.

With reference to the correlation coefficients, rather low levels of the strength of the bivariate correlations occur. In the overall sample parkour-related postings, training experience and gender share the highest-but still low-correlation coefficients, followed by the number of traceurs followed on social media and the frequency of the parkour training. The pkPSC in the media sample has the strongest correlation with the parkourrelated postings, followed by training experience, gender, followed traceurs and the training frequency in descending order. The third sample, which has been primed to compare the skills to the local training group, slightly differs from the two others: the highest correlation occurs between the pkPSC and the number of traceurs followed on social media, followed by training frequency, gender, training experience, parkour- related postings, and the duration of the social media use on a very low level.

Overall, these analyses statistically indicate the selected variables to be useful to explain the variance in the parkourrelated physical self-concept of traceurs and, so far, empirically support the assumption that social media use and selfassessment of parkour skills relate to each other. Although 'size of the training group' is not significantly linked to the pkPSC, content-issues regarding the different (sub)samples imply to include 'size of the training group' as an independent determinant into the regression models nevertheless.

The regression model for the overall sample explains $29.8 \%$ of variance in the parkour-related physical self-concept of the responding traceurs and can be interpreted as a large effect size following Cohen, Cohen, West, \& Aiken (2003). Within the overall sample, the training-related variables resemble the most important determinants of the pkPSC, given that the higher 'training experience' and 'frequency of parkour training' are, the better the traceurs assess their pkPSC (- Table 4). Furthermore, male and younger athletes have a significantly higher parkour-related physical self-concept than female and older athletes. Within the third dimension of determinants, postings of parkour-related content significantly increase the pkPSC, whereas the duration of the social media use and the number of athletes followed on social media can be considered as negligible. Likewise, the size of the training group is no significant predictor for the pkPSC.

The second model, representing the group that has been primed to athletes on social media, offers the best effect size with $32.1 \%$ explained variance in the pkPSC (- Table 4). As in the overall model, training experience influences the parkour-related physical self-concept the most; thus the second most important determinant is posting parkour-related content, emphasizing the relevance of social media use. Again, male and younger traceurs as well as athletes that practice parkour more often evaluate their parkour-skills as being significantly better than female, older, and less frequently practicing traceurs. The insignificant effects of duration of the social media use, number of athletes followed and size of the local training group, confirm the findings of the overall sample.

In the third regression model for the sample that has been primed to compare its skills to the local training group, the effect size decreased to an explained variance in the pkPSC of $27.9 \%$, this can still be considered a large effect (Cohen et al., 2003) (『 Table 4). As in the overall model, the two training variables have the strongest influence on the pkPSC with training experience being more important for the pkPSC than frequency of parkour training. The gender and age effects from the overall and the media samples are being confirmed, but on a lower level. The significance within the social media-related determinants shifts from parkour-related postings in the previously described two samples to the number of athletes followed on social media, indicating that a bigger parkour-related social media network leads to a higher evaluation of one's parkour skills. The irrelevance of duration of the social media use and size of the local training group is again, as in the other two models, being identified.

\section{Discussion}

Since parkour is a sporting activity, exercising both physical and mental skills in a real and tangible surrounding (Widmer, 2016), it is not surprising that train- 
Table 4 Multiple linear regression models for the parkour-related physical self-concept (pkPSC): overall sample 1, media sample 2, local sample 3. Regression coeffiecients (B), standard errors (SE), standardized beta-coefficients + significance levels $(\beta+\operatorname{Sig})\left({ }^{* * *} p \leq 0.001 ;{ }^{* *} p \leq 0.01 ;{ }^{*} p \leq 0.05\right)$, de termination coefficients Corrected $R^{2}$ and $R^{2}$, and sample size $(n)$. Significant standardized beta coeffcients are highlighted in italic

\begin{tabular}{|c|c|c|c|c|c|c|c|c|c|c|}
\hline & \multicolumn{3}{|c|}{ Overall sample (1) } & \multicolumn{3}{|c|}{ Media sample (2) } & \multicolumn{3}{|c|}{ Local sample (3) } \\
\hline & & B & $S E$ & $\beta+$ Sig & B & SE & $\beta+$ Sig & B & SE & $\beta+$ Sig \\
\hline- & Constant & 33.665 & 2.409 & $* * *$ & 32.022 & 3.651 & $* * *$ & 35.972 & 3.182 & $* * *$ \\
\hline \multirow{2}{*}{$\begin{array}{l}\text { Socio- } \\
\text { demo- } \\
\text { graphics }\end{array}$} & Gender (male) & 6.109 & 1.293 & $0.201^{* * *}$ & 7.297 & 1.803 & $0.242^{* * *}$ & 4.730 & 1.875 & $0.155^{*}$ \\
\hline & Age & -2.156 & 0.719 & $-0.132^{* *}$ & -2.748 & 1.062 & $-0.156^{* *}$ & -1.985 & 0.980 & $-0.134^{*}$ \\
\hline \multirow{3}{*}{$\begin{array}{l}\text { Parkour } \\
\text { training }\end{array}$} & Frequency of parkour training & 2.942 & 0.572 & $0.216^{* * *}$ & 2.294 & 0.894 & $0.154^{*}$ & 3.392 & 0.725 & $0.274^{* * *}$ \\
\hline & Training experience in parkour & 1.614 & 0.289 & $0.267^{* * *}$ & 1.805 & 0.430 & $0.283^{* * *}$ & 1.611 & 0.394 & $0.285^{* * *}$ \\
\hline & Size of training group in parkour & 0.402 & 0.449 & 0.037 & 1.108 & 0.688 & 0.095 & -0.095 & 0.58 & -0.009 \\
\hline \multirow{3}{*}{$\begin{array}{l}\text { Social } \\
\text { media } \\
\text { use }\end{array}$} & Duration of social media use & 0.654 & 0.594 & 0.045 & 0.107 & 0.911 & 0.007 & 1.217 & 0.766 & 0.092 \\
\hline & Parkour-related postings & 3.361 & 1.036 & $0.147^{* * *}$ & 6.337 & 1.528 & $0.271^{* * *}$ & 0.289 & 1.406 & 0.013 \\
\hline & $\begin{array}{l}\text { Number of traceurs followed in } \\
\text { social media }\end{array}$ & 1.562 & 0.930 & 0.077 & -0.509 & 1.484 & -0.023 & 2.962 & 1.164 & $0.159^{*}$ \\
\hline- & Corrected $R^{2}\left(R^{2}\right)$ & \multicolumn{3}{|c|}{$0.298(0.311)$} & \multicolumn{3}{|c|}{$0.321(0.348)$} & \multicolumn{3}{|c|}{$0.279(0.304)$} \\
\hline- & $n$ & \multicolumn{3}{|l|}{440} & \multicolumn{3}{|l|}{209} & \multicolumn{3}{|l|}{231} \\
\hline
\end{tabular}

ing-related variables play the dominant role in the self-assessment of a traceurs physical skills. In particular, because frequent training is long known to ameliorate skills and physical capacities, such as technique, strength, or stamina (Weineck, 2010), it seems rather obvious that training frequency acts as a main determinant for an athlete's sport-related physical self-concept. The relevance of training frequency for the evaluation of one's skills has previously been shown by Esnaola and Zulaika (2009) and even sport in general positively affects the (physical) self-concept (Balsalobre et al., 2014; Olmedilla et al., 2016). Furthermore, self-concepts are thought to be consolidated through experience, particularly due to the current evaluation of the self in various situations (Shavelson et al., 1976, p. 414). Thus, a great quantity of information gained through long-standing training experience consequently determines a more accurate and constant selfassessment. Associated with the enhancing relationship of training experience and pkPSC is the positive, two-sided effect of performance and the self-concept of athletes (Marsh et al., 2006).

Besides training-related aspects, gender impacts the pkPSC of traceurs leading to a more positive physical self-concept amongst male, compared to female traceurs. Fernandes (2018) previously ascertained that women are not only less represented within the parkour commu- nity, but also appear to feel inferior among male athletes. Since heterogeneous comparison-standards seem to be missing for female traceurs, they can only compare themselves to their male counterparts, leading to an engagement in dissimilarity testing (Mussweiler, Rüter, \& Epstude, 2004). Male practitioners, on the other hand, might, following that rationale, assimilate more towards their male peers. This seems even more applicable, considering that the average local training group consists mostly of only five athletes. Following Schäfers' (1999) definition, the partakers of a small group would then be participating in a constant interaction to achieve a common goal and thus develop a feeling of affiliation leading to a more positive selfassessment if this group serves as routine comparison standard (Blanton, Crocker, \& Miller, 2000; Mussweiler \& Bodenhausen, 2002) and if the general skill-level of the fellow traceurs appears to be attainable to the athlete (Lockwood \& Kunda, 1997). Furthermore, parkour is mainly still perceived and depicted as a maledominated, high-risk youth-sport, either in media, society (Angel, 2011), or even science (e.g., Miller \& Demoiny, 2008). Consequently, it appears comprehensible that women, as well as older athletes, do not correspond well with the dominant imagery and actual demographic of the discipline, even though the philosophy of the sport celebrates diversity, safety, togetherness, and respect (Widmer, 2016).

The third type of determinants covered the social media use and the only determinant positively affecting the pkPSC of the overall sample is the posting of parkour-related content. The more parkour-related content traceurs share on social media and online communities, the better they evaluate their physical selfconcept. This might be partly explained by an increase in the self-assessment of one's parkour skills due to positive feedback in terms of likes, comments, shares etc. of the online community and specific experts (Braumüller, 2020). Turning around the causality offers further interpretative perspectives on this effect: Thus, it might not be the active posting behavior that is predicting a high pkPSC, but a high pkPSC that is predicting, or at least fostering, an active posting behavior. Therefore, athletes with a high opinion of themselves and their skills may create more content to share because they are aware of their skills and competencies. This would give rise to an unspoken hierarchy of the discipline, in which athletes with good skills and/or styles are being valued (Angel, 2011; Wheaton \& Gilchrist, 2012). Moreover, active social media participation is being seen as essential for authenticity in informal sports like parkour (Wheaton \& Gilchrist, 2012) and may consequently lead to a higher 
rate of involvement, when longer or more intensively integrated in the activity.

Taking a look at the relevance of the three types of independent variables, the highest impact on the pkPSC occurs within the training-related variables with training experience and frequency of training being particularly important (Esnaola \& Zulaika, 2009). Interestingly, the size of the training group, demonstrating possible comparative perspectives in terms of the amount of people to which a traceur can regularly compare his/her skills, does not significantly impact the pkPSC. Within the sociodemographic characteristics, gender and age influence the pkPSC considerably, in all models, thus, confirming the scope of literature (Angel, 2011; Babic et al., 2014; Fernandes, 2018; Grosprêtre \& Lepers, 2016). Within the social media determinants, posting parkour-related content determines the pkPSC of traceurs significantly, but the duration of the social media use and the number of traceurs followed do not.

Comparing the three models to each other we can conclude that gender, age, frequency of parkour training, and training experience in parkour significantly determine the pkPSC in each of the models. Parkour-related postings affect the self-assessment of parkour skills in the overall and the media sample, whereas the number of traceurs followed influences the pkPSC of athletes that have been primed to the local training group. Possible reasons for this distribution remain unclear, though. Comparing the effect sizes of the independent determinants between the three models, it appears that the sociodemographic characteristics and the respectively significant social-media related variable share their highest impact in the media model, whereas the highest values for the training-related variables occur in the local sample, which could be an outcome of the priming effect.

\section{Conclusion and limitations}

Before drawing a final conclusion of the current study, some limitations concerning its design and database, as well as future perspectives should be discussed.
First of all, the cross-sectional data has to be mentioned as a data limitation that, strictly speaking, does not allow for causal analyses. For some of the independent variables, causal relationships with the dependent variable pkPSC can be contextualized and assumed, e.g., training-related variables or sociodemographic characteristics, whereas for others, causalities can be in either direction. The relationship of the active posting behavior and the pkPSC of the traceurs serves as an example, which has been discussed above. Due to this problem of causality, longitudinal data would enrich the analytical perspectives enabling scientists to derive unambiguous causal effects in future research.

Furthermore, the data collection and the secondary data in general account for some limitations of the present study. First, the online-based data collection could have had an impact on the dataset, as discussed in Holzmüller's (2018) initial study. Especially, the all-text layout could have led to less pronounced priming, ultimately biasing the results. Additionally, satisficing strategies (Krosnick, Narayan, \& Smith, 1996; Krosnick, 1999) could have been triggered by the Likert scale design. Furthermore, the questionnaire did not take other sporting activities that might also affect the physical self-concept into account. Thus, it was emphasized several times throughout the questionnaire that parkour-related training and social media use was the focus. The sample is still thought to be a good representation of the overall population of traceurs, due to the parkour community's high online activity, which was used to distribute the questionnaire in the community, as well as the studies congruence with preexisting results.

Second, some of the ordinal scaled variables (e.g., age, training experience or social media use) did not perfectly meet the requirements of regression analysis, since they did not show equal distances. Due to the relevance of the related content these variables were nonetheless integrated. With reference to the data analysis, the usefulness of a sum value for the pkPSC has to be discussed, since it neglects possible impacts of the determinants on either physical abilities or style/ aesthetics. But the chosen approach corresponds to a holistic perspective on the self-concept and also the sport parkour.

Third, the theoretically derived physical self-concept of traceurs has to be discussed in terms of its limitations. Holzmüller (2018) found the pkPSC to be immature and in need of statistically derived, more nuanced, foundations. Particularly a revised weighting of the various components would improve the pkPSC, since-in Holzmüller's (2018) opinion-qualities like stamina or movement precision seem to be of different value to the athletes, based on the discipline's demands. This opens up qualitative research perspectives examining the evaluation and weighting of typical skills, as well as physical and mental competencies that constitute the physical self-concept of traceurs in interviews with experts and/or athletes. Furthermore, as Braumüller $(2017,2020)$ has shown, qualitative data facilitate deeper insights into the relationship of sport and social media activities, which would be useful to empirically study the theoretically assumed, particularly strong and enriching relationship of social media, parkour, and the self-assessment of parkour-skills.

Besides qualitative approaches, further multivariate and multidimensional quantitative research should focus on increasing the explained variance of the self-assessment of traceurs, which varied in the current regression analyses between $28 \%$ in the local sample and $32 \%$ in the media sample. Thus, due to the consideration of latent structures as well as latent contributing factors, structural equation models might function as an expedient method to strengthen our knowledge on the determining factors of the physical self-concept of traceurs and other informal and organized athletes as well.

With regard to the research question, we can conclude that a high parkourrelated physical self-concept is mainly determined by the actual amount of time athletes put into their training activities (frequency of training and years of training experience) and thus, through practice-associated learnings, adaptations, and observations about their technique, 
skill, and self. A hierarchical gender order is evident in parkour (Fernandes, 2018) as in other trend, youth, or risk sports, which is reflected in the highly important determinant of being male for a higher parkour-related physical self-concept. Being a young male still is the predominant sociodemographic characteristic in parkour and impedes inclusive structures for females or older participants into the community. Finally, the influence of active posting habits on the pkPSC might be interpreted as causal in both directions, in which not only the posting frequency predicted a higher pkPSC, but also the self-assessment of skills increased the posting behavior of traceurs. Although parkour and social media share a strong and enhancing relationship, the parkour-related physical self-concept is more impacted by reallife activities and characteristics than by social media habits; thus, this finding should not lead to the assumption of a decreasing impact of social media on informal sports like parkour.

\section{Corresponding address}

Dr. Birgit Braumüller
Institute of Sociology and
Gender Studies, German
Sport University Cologne
Am Sportpark Müngersdorf 6,
50933 Cologne, Germany
b.braumueller@dshs-
koeln.de

Funding. Open Access funding provided by Projekt DEAL.

\section{Compliance with ethical guidelines}

Conflict of interest. P.J.J. Holzmüller and B. Braumüller declare that they have no competing interests.

For this article no studies with human participants or animals were performed by any of the authors. All studies performed were in accordance with the ethical standards indicated in each case.

Open Access This article is licensed under a Creative Commons Attribution 4.0 International License, which permits use, sharing, adaptation, distribution and reproduction in any medium or format, as long as you give appropriate credit to the original author(s) and the source, provide a link to the Creative Commons licence, and indicate if changes were made. The images or other third party material in this article are included in the article's Creative Commons licence, unless indicated otherwise in a credit line to the material. If material is not included in the article's Creative Commons licence and your intended use is not permitted by statutory regulation or exceeds the permitted use, you will need to obtain permission directly from the copyright holder. To view a copy of this licence, visit http://creativecommons.org/licenses/by/4.0/.

\section{References}

Angel, J.M. (2011). Cine parkour: a cinematic and theoretical contribution to the understanding of the practice of parkour. London: Brunel University.

Babic, M. J., Morgan, P. J., Plotnikoff, R.C., Lonsdale, C., White, R. L., \& Lubans, D. R. (2014). Physical activity and physical self-concept in youth: systematic review and meta-analysis. Sports medicine, 44(11), 1589-1601.

Balsalobre, F.J.B., Sánchez, G.F.L., \& Suárez, A.D. (2014). Relationships between physical fitness and physical self-concept in Spanish adolescents. Procedia-Social and Behavioral Sciences, 132, 343-350.

Blanton, H., Crocker, J., \& Miller, D.T. (2000). The effects of in-group versus out-group social comparison on self-esteem in the context of a negative stereotype. Journal of Experimental Social Psychology, 36, 519-530.

Bock, K. (2017). Kommunikative Konstruktion von Szenekultur. Skateboarding als Sinnstiftung und Orientierung im Zeitalter der Digitalisierung. Weinheim: Beltz Juventa.

Braumüller, B. (2016). Hockey im Club oder Skaten im Park? Eine Sekundäranalyse der MediKuS-Studie zur Sozialisation in vereinsorganisierte und informelle Sportsettings in Abhängigkeit von sozialen, personalen und medialen Ressourcen in der Adoleszenz. Sport und Gesellschaft, 13(3), 215-249.

Braumüller, B. (2017). Sportbezogenes Handeln in virtuellen sozialen Netzwerken. Bedeutung und Relevanz für das Sporttreiben und die sportive Identitätjunger Erwachsener. German Journal of Exercise and Sport Research, 48(1), 79-88.

Braumüller, B. (2020). Young adults' perceptions of the relevance of interaction on social online networks for sports activities. European Journal for Sport and Society. https://doi.org/10.1080/ 16138171.2020.1792072.

Braumüller, B., \& Hartmann-Tews, I. (2017). Jugendliche als mediatisierte Stubenhocker? Eine Analyse der Zusammenhänge zwischen sportlichem und medialem Handeln von Jugendlichen aus Geschlechterperspektive. Diskurs Kindheits- und Jugendforschung, 12(1), 49-70.

Chou, H.G., \& Edge, N. (2012). "They are happier and having better lives than I Am": the impact of using Facebook on perceptions of others lives. Cyberpsychology, Behavior, and Social Networking, 15(2), 117-121.

Cohen, J., Cohen, P., West, S. G., \& Aiken, L. (2003). Applied multiple regression/correlation analysis for the behavioral sciences (3rd edn.). Mahwah: Lawrence Erlbaum.

Cooley, C. H. (1902). Human nature and the social order. New York: Scribner's Sons.

David, J.L., Powless, M.D., Hyman, J.E., Purnell, D. J.M., Steinfeldt, J.A., \& Fisher, S. (2018). College student athletes and social media:
The psychological impacts of Twitter use. International Journal of Sport Communication, 11(2), 163-186.

Döring, N. (2014). Peer-to-Peer-Gesundheitskommunikation mittels Social Media [Peer-to-peer health communication via social media. In K. Hurrelmann \& E. Baumann (Eds.), Handbuch Gesundheitskommunikation (pp. 286-305). Bern: Huber.

Esnaola, I., \& Zulaika, L. M. (2009). Physical activity and physical self-concept in a sample of middleage basque adults. Perceptual and Motor Skills, 108(2), 479-490.

Fernandes, A. V. (2018). Transpondo muros socioculturais: Relações de gênero e empoderamento de mulheres no parkour. Maringá: Universidade Estadual de Maringá, Departamendo de Educação Física.

Festinger, L. (1954). A theory of social comparison processes. Human Relations, 7, 117-140.

Fox, J., \& Moreland, J.J. (2015). The dark side of social networking sites: An exploration of the relational and psychological stressors associated with Facebook use and affordances. Computers in Human Behavior, 45, 168-176.

García, F., \&Musitu, G. (2001). AF5: Autoconcepto Forma 5. Madrid:TEA.

Gonzales, A. L., \& Hancock, J.T. (2011). Mirror, mirror on my Facebook wall: effects of exposure to Facebook on self-esteem. Cyberpsychology, Behavior, and Social Networking, 14(1), 79-83.

Grabe, S., Ward, L. M., \&Hyde, J. S. (2008). The role of the media in body image concerns among women: a meta-analysis of experimental and correlational studies. Psychological Bulletin, 134,460-476.

Grosprêtre, S., \& Lepers, R. (2016). Performance characteristics of Parkour practitioners: Who are the traceurs? European Journal of Sport Science, 16(5), 526-535.

Holzmüller, P. (2018). Parkour, Fische und das Netz. Eine Studie über die Selbsteinschätzung des parkourbezogenen physischen Selbstkonzepts von Traceuren in lokalen Trainingsgruppen und den sozialen Medien orientiert am Big-Fish-LittlePond-Effekt. Cologne: German Sport University Cologne. Institute of Sociology and Gender Studies.

Jones, J. M. (2015). The looking glass lens: self-concept changes due to social media practices. The Journal of Social Media in Society, 4(1), 100-124.

Kim, D., Kim, S. Y., \& Choi, M.I. (2016). Why young people use social media for sports: a uses and gratifications perspective. Indian Journal of Science and Technology. https://doi.org/10. 17485/ijst/2016/v9i26/97403.

Krosnick, J. A. (1999). Survey research. Annual Review of Psychology, 50,537-567.

Krosnick, J. A., Narayan, S. S., \& Smith, W. R. (1996). Satisficing in surveys: Initial evidence. In M.T. Braverman \& J.K. Slater (Eds.), Advances in Survey Research (pp. 29-44). San Fransisco: Jossey-Bass.

Krotz, F. (2017). Sozialisation in mediatisierte Welten. Mediensozialisation in der Perspektive des Mediatisierungsansatzes. In D. Hoffmann, F. Krotz \& W. Reißmann (Eds.), Mediatisierung und Mediensozialisation. Prozesse-Räume-Praktiken (pp. 21-40). Springer

Lockwood, P., \& Kunda, Z. (1997). Superstars and me: predicting the impact of role models on the self. Journal of Personality and Social Psychology, 73, 91-103.

Lup, K., Trub, L., \& Rosenthal, L. (2015). Instagram \#Instasad?: exploring associations among Insta- 
gram use, depressive symptoms, negative social comparison, and strangers followed. Cyberpsychology, Behavior, and Social Networking, 18(5), 247-252.

Marsh, H. W., \& Parker, J.W. (1984). Determinants of student self-concept: Is it better to be a relatively large fish in a small pond even if you don't learn to swim as well? Journal of Personality and Social Psychology, 47, 213-231.

Marsh, H. W., Chanal, J., \& Sarrazin, P. (2006). Self-belief does make A difference: a reciprocal effects model of the causal ordering of physical selfconcept and gymnastics performance. Journal of Sports Sciences, 24(1), 101-111.

Marsh, H.W., Martin, A.J., \& Jackson, S. (2010). Introducing a short version of the physical self description questionnaire: new strategies, shortform evaluative criteria, and applications of factor analyses. Journal of Sport and Exercise Psychology, 32(4), 438-482.

Miller, J.R., \& Demoiny, S.G. (2008). Parkour: a new extreme sport and a case study. The journal of foot and ankle surgery, 47(1), 63-65.

Mussweiler, T., \& Bodenhausen, G. V. (2002). I know you are, but what am I? Self-evaluative consequences of judging in-group and out-group members. Journal of Personality and Social Psychology, 82, 19-32.

Mussweiler, T., Rüter, K., \& Epstude, K. (2004). The ups and downs of social comparison: Mechanisms of assimilation and contrast. Journal of Personality and Social Psychology, 87, 832-844.

Nunnally, J.C., \& Bernstein, I. H. (1994). Psychometric theory (3rd edn.). New York: McGraw-Hill.

Olmedilla, A., Toro, E. O., \& Abenza, L. (2016). Selfconcept, sport, and physical activity practice in university students. Journal of human sport \& exercise, 11(4), 415-425.

O'Reilly, N., Berger, I., Hernandez, T., Parent, M., \& Seguin, B. (2012). Understanding adolescent sport participation through online social media. Sport, Business and Management: An International Journal, 2(1), 69-81.

Royal Society for Public and Health (2017). Social media and young people's mental health and wellbeing. London: Royal Society for Public and Health.

Schäfers, B. (1999). Entwicklung der Gruppensoziologie und Eigenständigkeit der Gruppe als Sozialgebilde. Einführung in die Gruppensoziologie, 3, 19-34.

Schwier, J. (2008). Inszenierungen widerspenstiger Körperlichkeit. Zur Selbstmediatisierung jugendlicher Sportszenen. Zeitschrift für Soziologie der Erziehung und Sozialisation, 28(3), 271-282.

Schwier, J., \& Erhorn, J. (2015). Trendsport. In W. Schmidt, N. Neuber, T. Rauschenbach, H.P. Brandl-Bredenbeck, J. Süßenbach \& C. Breuer (Eds.), Dritter Deutscher Kinder- und Jugendsportbericht. Kinder- und Jugendsport im Umbruch (pp. 179-200). Schorndorf: Hofmann.

Setzer, M., Ernst, C., \& Miethling, W.D. (2014). Bewegungspraxen im Internet. Eine Studie zur Selbstdarstellung jugendlicher Windsurfer in sozialen Netzwerken [Movement practices on the Internet. A study on the self-presentation of young windsurfers in social networks. Medien und Sport, 36(4), 18-21.

Shavelson, R.J., Hubner, J.J., \& Stanton, G.C. (1976). Self-concept: Validation of construct interpretations. Review of educational research, 46(3), 407-441.

Spengler, S. , Mess, F. , \& Woll, A. (2015). Do media use and physical activity compete in adolescents?
Results of the MoMo study. PLoS One, 10(12), e0142544. https://doi.org/10.1371/journal. pone. 0142544

Suchert, V., Hanewinkel, R., \& Isensee, B. (2016). Screen time, weight status and the self-concept of physical attractiveness in adolescents. Journal of Adolescence, 48, 11-17.

Want, S.C. (2009). Meta-analytic moderators of experimental exposure to media portrayals of women on female appearance satisfaction: Social comparisons as automatic processes. Body Image, 6, 257-269.

Weineck, J. (2010). Optimales Training (16th edn.). Hamburg: Czwalina.

Wheaton, B., \& Gilchrist, P. (2012). New media technologies in lifestyle sport. In B. Hutchins \& D. Rowe (Eds.), Digital media sport: technology, power and culture in the network society (pp. 169-186). London: Routledge.

Widmer, R. (2016). Burner: Parkour. Schorndorf: Hofman Verlag. 